\title{
The love poetry of Shelomoh ben Reuben Bonafed. Hebrew poems and courtly love.
}

Love poetry has always been seen as a separate "genre", and perhaps the most emblematic of all genres, in the lyrical production of any society or culture. Such an assumption is certainly implicit in classic studies of what is known as Hispano-Hebrew literature. In the traditional classifications of Andalusi Hebrew poetry and, by extension, of all Hebrew poetry written in the peninsular Christian realms, love poetry is usually treated as one of the genres of classical Arabic poetry consumed and produced by the Andalusi literary figures who "adapted" and "adopted" it.

Thus it is that most studies of medieval Hebrew love poetry focus on identifying the genetic origins of the genre in classic Arabic literature by tracing in Hebrew love poems common topoi or expressions which reinforce a relationship of interdependence between the two literatures. Such analysis tends not to pay much attention to the specific details of how Jewish societies differed over time and space, and it conceives of "medieval Hebrew literature" as a continuous whole from the time of its origins until the expulsion of 1492 .

Nevertheless, studies by a number of recent scholars have succeeded in breaking down this traditional assumption and have started to place the literature produced by Hebrew authors in the peninsular kingdoms within specific cultural contexts. The work carried out by Eliezer Gutwirth ${ }^{1}$, Ángel Sáenz Badillos ${ }^{2}$, Judit Targarona ${ }^{3}$ and Raymond P. Scheindlin ${ }^{4}$ has been of particular importance in this regard ${ }^{5}$.

\footnotetext{
${ }^{1}$ For example: Gutwirth, "Social Criticism in Bonafed's Invective and its Historical Background"; "The World Upside Down in Hebrew"; "Leer a Bonafed en su entorno".

${ }^{2}$ For example: Sáenz-Badillos, "Relaciones entre la poesía hebrea y las literaturas romances. Estado actual del problema"; "Selomoh Bonafed at the crossroad of Hebrew and romance cultures"; "Šelomoh Bonafed, último gran poeta de Sefarad, y la poesía hebrea".

${ }^{3}$ For example: Targarona Borrás, "Los últimos poetas hebreos de Sefarad: poesía hebrea en el mundo románico".

${ }^{4}$ For example: Scheindlin, "Secular Hebrew Poetry in fifteenth-century Spain"; "The Hebrew Qasida in Spain".

${ }^{5}$ There are many important scholarly contributions which focus in the contextualization of the Hebrew literary production on the area of Ashkenaz into their Romance (French) or German-Christian cultural milieu. I will mention just one article specially significant to this work. This article focus on the contextualization of a thirteenth century Hebrew commentary on Song of Songs written in north France during the $13^{\text {th }}$ century in its romance-French cultural milieu attending to the chivalry literature and the
} 
My intention in this article, which seeks to follow modestly in the wake of these researchers, ${ }^{6}$ is to contextualize the love poetry written by Shelomo Bonafed, the early fifteenth-century Hebrew author from the kingdom of Aragon. I do this by placing him firmly within the cultural and social framework in which he lived, rather than examining his work in relation to the Hebrew love poetry that had been written two centuries earlier in al-Andalus or that which was composed half a century later, outside the Iberian peninsula.

My aim is to offer a literary contextualization of Bonafed's love poetry by examining contemporary literary productions on the theme of love that will aid a reading of his poems. This does not mean that I consider it necessary to reject all comparisons with the Hebrew love poetry of previous periods, for Bonafed also clearly writes literature in Hebrew. However, I hope to show that Bonafed's practice was to reuse and re-establish this tradition, furnishing it with new forms and a new meaning within his own cultural and social context, that of early fifteenth-century Aragon.

In this article I will use the various poetics of love which were common in the literature of Bonafed's time to understand his own poetry, attending, in particular, to the recurrent motifs of love in both Provençal and Romance (Catalan and Castilian) literature, and the techniques of poetic composition which can help us to locate Bonafed's love poetry within its context. Before starting to do this, however, I would first like to outline the corpus of texts by Bonafed which I have drawn upon in undertaking this study.

There are four love poems and other works by Bonafed in which the theme of love is mentioned or plays a central role. The first of these poems appears in a letter written to a woman called Simha ${ }^{7}$ which is headed "To a beautiful girl whom I liked"; another two poems were addressed to a woman by the name of Malkah, ${ }^{8}$ and the fourth work is a muwwashah addressed to a woman called Sol (ك̌emeš). ${ }^{9}$ In addition to these works, the theme of love is also dealt with in a wedding poem addressed to the bridegroom Yosef on the occasion of the famous wedding in Agramunt; ${ }^{10}$ in a poem of praise addressed to (Yosef) Vidal ben Labi (Gonzalo de la Caballería) on the occasion of "the passing of winter and rain and the coming of the season which is the time of

love concepts which are present in it: Japhet, "The Lovers'Way": Cultural Symbiosis in a Medieval Commentary on the Song of Songs".

${ }^{6}$ Of particular importance to my work is the article by Sáenz-Badillos, "Selomoh Bonafed at the crossroad of Hebrew and romance cultures".

${ }^{7}$ I will cite poems by the first words of their first verse and their place in the ms. Mich 1984 of the Bodleian Library of Oxford: be-mișhi huqqequ fol. 15v-16v.

${ }^{8}$ bi me'anah 'ofrah fol. 16v-17r; Šemeš be-lehyah fol 17r.

9 Šemeš zarehah fol. $103 \mathrm{v}-104 \mathrm{r}$.

${ }^{10}$ yonah be-tok sipporim fol. 56r-57r entitled by Bonafed himself 'ateret paz. Poem published in: Vardi, "A wedding in Agramunt: The wedding poems of Solomon Bonafed". 
love"; ${ }^{11}$ in three poems containing a dispute on the subject of "love" between Bonafed and the young poet Yahseel ha-Qaslari, who rebukes his master Bonafed for professing illicit love for a woman; ${ }^{12}$ and, finally, the theme is also a feature of a further three poems in which Bonafed defends himself against the attacks of another young poet who disapproves of his beloved, who may or may not be the same woman as in the previous work. In these last three poems, Bonafed asks other poets for assistance in calming his beloved's father, who has come between the two lovers, and ends by bewailing the fact that the father has sent his daughter on a sea-journey to Sicily in order to prevent the girl from enjoying further contact with him. ${ }^{13}$

Contrary to first impressions, poems with a love theme do not constitute a majority in those of Bonafed's writings that have come down to us, and I would go so far as to say that the same is true of the poetic works of other contemporary authors. Poems of praise or condemnation make up most of his works, although as we have seen, something can also be learnt about the conception of love poetry and its topics in Bonafed's work from an examination of some of his other poems.

By the fifteenth century, the various Romance cultures already developed a rich and sophisticated culture which incorporated the use of Latin and works produced in that language. These were works that had come down from the Romans themselves but also included works written in the medieval period, within an incipient pre-modern vernacular production in which humanism was the element that had begun to transform the cultural panorama ${ }^{14}$. The first half of the century saw a massive translation ${ }^{15}$ of Latin or Italian works into Castilian and Catalan, which became the "literary languages" of the fifteenth century.

It is within this context of emerging vernacular literatures, in which a series of different cultural and national identities were under construction, that the Hebrew literature produced by Bonafed and other Hebrew poets of his time must be located.

The literary panorama of fifteenth-century Aragon can be seen as divided into three main bodies of writing. Firstly, there was the literature of the troubador tradition, with works composed in Provençal/Occitan or langue d'oc. This kind of literature was

11 'aloz lev 'asir tiqva, Poem published in: Schirmann, Ha-širah ha- 'ivrit bi-Sefarad u-ve-Provans, poem 450, 623-625.

12 The three poems comprising this dispute are: Yahhseel's poem reprehending Bonafed (le-ka dodi le-ka fol. 38r-39r); Bonafed's reply to Yahḥseel (te 'alah 'aletah fol. 39v-40v), and another reply by Bonafed to Yahhseel ('al na' taribeni fol. 40v-41r).

1313 lebabi 'ahre nimkar 17r-17v. The name of the beloved appears to be Sun, perhaps the same Sun as in the poem Šmeš zarehah fol. 103v-104r.; [and] the poem lebabi qera'tiw be-qor' $i$ fol. $17 \mathrm{v}-18 \mathrm{r}$. Written after tearing up the letter received from the young poet. The signature of the poem is: libbi we-nafši fol. 18r.; and the poem [sic] bekhu 'ahabah fol. 18r-18v. written by Bonafed after hearing of his beloved's departure on a ship bound for Sicily.

${ }^{14}$ For the beginning of humanism in the Iberian Peninsula see: Gómez Moreno, España y la Italia de los humanistas: Primeros Ecos.

${ }^{15}$ For transalations in the fifteenth century see: Alvar and Lucía Megías, Repertorio de traductores del siglo $X V$. 
widely known at the courts of the Provence region itself, but was also familiar to the kingdoms of Aragon and Castile. A second group was that of texts written in Latin, and a third that of the literatures produced in Castilian, Italian, Catalan etc, which were in turn enriched by the profusion of translations among those languages and from Latin. The Hebrew literature produced by Bonafed can be seen as another group to add to this raft of written traditions and it is important to realise that it was one that was not cut off from the rest, just as none of the others were isolated from each other. ${ }^{16}$ The theme of love illustrates this link, and I will now explore how the different concepts of love and its literary treatment in these various Romance traditions are important to an understanding of Bonafed's work.

The concept of love which seems to be common to all of these traditions is that of a dialectical opposition, which is sometimes resolved and on other occasions firmly opposed, between a "human" or "carnal" love and a "pure" or "spiritual" love pertaining to the divine rather than the human sphere.

The poetic tradition of the troubadors of the eleventh and twelfth centuries was still consumed by readers and courtly audiences through the troubadors, jongleurs and books of the fifteenth century. This long and rich tradition can be seen to have altered its conception of love over time if we examine the different authors and periods of its production. However, it is possible to identify two main strands or tendencies. In one of them, poets dedicated their poetry to a concept of love that was highly charged with sexual desire and eroticism. Such poetry was occasionally addressed to married women, as for example in the poems of Bernat de Ventadorn ${ }^{17}$ or in the concept of love found in Andreas Capellanus. ${ }^{18}$ In the second strand, the concept of love swaps its human sexual referent for that of divine contemplation. In this kind of poem, interest focuses on "love of God", though expressed in human words. The aim of such poetry is to pursue perfection in faith instead of indulging in the banal play of courtly love. This tendency is exemplified by the work of a poet such as Marcabru ${ }^{19}$ or the Breviari d'amor by Mangfred Armengaud. ${ }^{20}$

\footnotetext{
16 The other literary tradition which should perhaps be mentioned here is that written in Arabic, which is certainly not marginal to the theme of this article, although this would need to be the subject of a further study.

17 A late $12^{\text {th }}$-century troubador. He is a representative of the "trovar leu". See De Riquer, Los Trovadores. Historia literaria y textos, vol. 1, 342-418.

${ }^{18}$ Andreas Capellanus (twelfth century), author of the famous treatise De Amore which became a work of reference for so-called courtly love in the nineteenth century. See Capellanus, De Amore.

${ }^{19}$ A mid 12th-century troubador who worked at several peninsular courts. He is the paradigmatic representative of the "trovar clus". See De Riquer, Los Trovadores. Historia literaria y textos. vol. 1, $170-220$

${ }^{20}$ Bolduc, "The Breviari d'Amor: Rethoric and Preaching in Thirteenth-Century Languedoc", 409. For an explanation of the anti-cathar content of the book see page 419 and ff.
} 
In this tradition, "carnal" or "passionate" love is considered a form of madness or folly (fols) which has to be controlled by "moderation" 21 if it is not to become destructive, whereas spiritual love, as a reflection of divine love, is "pure". This conception is formulated in the scholastic tradition ${ }^{22}$ and is reflected in various vernacular poetic works and essays, such as the treatise on Love by Alonso Fernández de Madrigal, known as "El Tostado", ${ }^{23}$ in which the author explains a man's need to love. In this text, carnal love or "passion" is responsible for detaching the lover from reason, since reason is perceived as the only thing that can cure or save men from the impassioned love which drives them mad. The text is presented in the form of a dialogue, as a reply to a "brother" who has scolded El Tostado for falling in love. El Tostado justifies his infatuation and momentary madness or detachment from reason in the following terms:

You reprehend me, brother, because the love of a woman perturbed me, or virtually exiled me from the bounds of reason, which leads you to express wonder as at some novelty. And because the complaint caused by love was then my gaoler, I had not the liberty to satisfy you with a worthy response, but now that inasmuch as I have been abandoned, not by love but rather by passion, I would like to rid myself of the offence of which you accuse me, contradicting your rebuke, because you forgot that subject of which you are a scholar. And in order that you may believe that in loving I did the right thing and in loving I did not err in being perturbed, I put to you these two conclusions: firstly, that it is needful for a man to love; and secondly, that it is needful for he who loves properly and truly on occasions to be perturbed. ${ }^{24}$

A very similar text appears in Bonafed's poem le-kha dodi le-kha, where Yahḥseel ha-Qaslari rebukes Bonafed for his "desire" and expresses wonder that an "intelligent" man i.e. a man with the ability to reason, can allow himself to be deceived by carnal love and abandon his rationality:

"I wonder at the fact that someone perfect in his intellect as you are / goes after love ${ }^{25}$ and its vanities. // How could you, turban of my head, be infatuated ${ }^{26}$ with a stranger $?^{27} /$ How could you desire ${ }^{28}$ her beauty

\footnotetext{
${ }^{21}$ For a brief description of the term see De Riquer, Los Trovadores. Historia literaria y textos, vol. 1, 8889.

${ }^{22}$ For a complete description of the scholastic concept of love see Morgan, "Natural and Rational Love in Medieval Literature," 45.

${ }^{23}$ Alonso Fernández de Madrigal, "El Tostado" (1410-1455). He was the bishop of Ávila, a famous writer and Biblical commentator.

${ }^{24}$ M. Cátedra, Tratados de amor en el entorno de Celestina,55:

"Reprendísteme, hermano, porque amor de muger me turbó, o poco menos desterró de los términos de la razón, por que te maravillas como de nueva cosa. Et porque la quexa por amor cabsada era entonçes mi prisionera, non ove libertad para te satisfazer con digna respuesta, mas agora que yaquanto me desanparó no el amor, mas la pasión, quiero apartar de mí la culpa de que me acusas, contradiciendo tu reprehensión, porque diste a olvido aquello que eres estudioso. E porque creas que en amar fize cosa devida e, amando, no erré en me turbar, pongo e fundarte he dos conclusiones: primera, que es neçesario al omne amar; segunda, que es nesçesario al que propia e verdaderamente ama que algunas vezes se turbe."

${ }^{25}$ Pro 5:19. The reference is to the whole passage, because the next verse quotes the following verse.

${ }^{26}$ In the original context of Pro 5:19-20: "Find joy in the wife of your youth......be infatuated with love of her always. Why be infatuated, my son, with a forbidden woman?"

${ }^{27}$ Pro 5:20.

${ }^{28}$ He uses the same verb used in the Ten Commandments to prohibit desiring/coveting the wife of another: Ex. 20:14: “you shall not covet your neighbour's wife".
} 
or her voice? // The faults of a great man are counted, / but they are inscribed in the book with a stylus of iron $^{29},, 30$

Bonafed answers the young poet in terms that are reminiscent of those used by Alonso Fernández de Madrigal. He admits to the impotence of man in the face of desire and cites examples of Biblical archetypes representing surrender to uncontrolled carnal desire and which justify the momentary madness brought on by this kind of love:

"Don't rebuke me, I pray you, because of the love for that dove // that afflicts with her tricks whoever knows the wisdom. // Listen to my weeping, my beloved, because love is like a spark, // look what happened to Amnon, Sekem and Dinah. // The law and the precepts of her love are fire, and I am sulphur"31.

The use of Biblical archetypes to exemplify madness and the pain of carnal love is a feature of other poems by Bonafed on the subject of love. ${ }^{32}$ One example can be seen in another reply made by the poet to the reproaches of Yahseel in the poem te 'alah 'aletah:

"Look what Love did in the past with Sekem's desire // for Dinah, to the extent that he was circumcised. // Is it not incredible that Amnon could have loved his sister? // Or that Dalilah tied Samson? // Alas, for none of them suffered a pain comparable to mine." ${ }^{33}$

This Biblical motif is repeatedly found in the Hebrew literature of the period and also in Provençal and Castilian literature, in both cases when referring to carnal love. The following Provençal poem by Marcabru takes the form of a dialogue between Catola and the poet:

"Do you not know how love betrayed Samson? ... // ...we can find evidence referring to the mighty Samson and his wife, showing that she had withdrawn her love for him at the moment he was annihilated... // Catola, the love of which you speak switches deceitfully the dice. Solomon and David warn you to take good care of yourself after a good success." 34

This deployment of pairs of Biblical lovers to exemplify carnal love is found throughout fifteenth-century Romance literature, where classical lovers are often used

\footnotetext{
${ }^{29}$ The sins of a great man are few in number, but worse in quality. He might mean that the sin of a sage counts like various sins of a simple man.

${ }^{30}$ le-kha dodi le-kha fol. 38r-39r. verses 20-22:

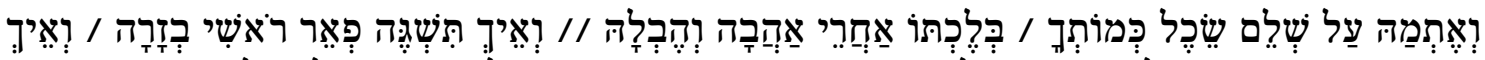

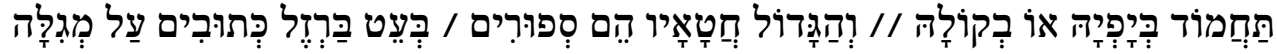

${ }^{31}$ al na' tariveni fol. 40v-41r. verses 1-3:

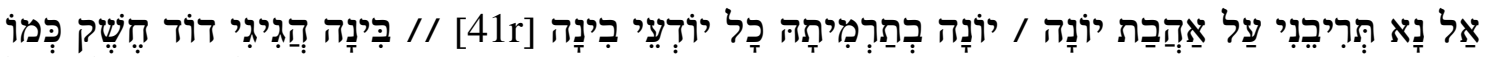

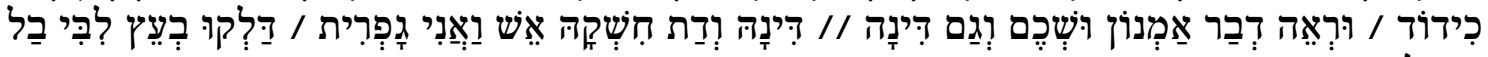

${ }^{32}$ This motif is also used in the wedding poem to Yosef: Vardi, "A wedding in Agramunt".

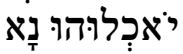

${ }^{33}$ te' 'alah 'aletah fol. $39 \mathrm{v}-40 \mathrm{v}$. verses 25-27:

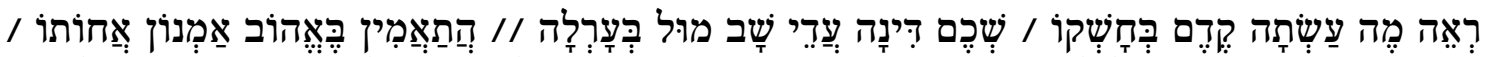

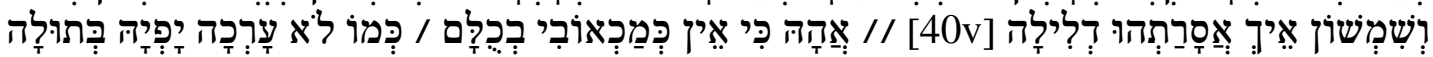
34 Amics Marchabrun, car digam, in De Riquer, Los Trovadores. Historia literaria y textos, vol. 1, 192: "Non saps d'amor cum trais Samson?...//...Catola, l'amors dont parlaz // camja cubertament los daz; // aprop lo bon lanz vos gardaz! // ço dis Salomons e David."
} 
alongside others from the Bible. One example is the same motif in two of the treatises of Alonso Fernández de Madrigal, ${ }^{35}$ in his Breviloquio de amor e amiçiçia, which has a chapter exemplifying the passion of Phaedra and Hippolytus by reference to that of Amnon and Tamar, ${ }^{36}$ and in the previously cited treatise, the Tratado de como al hombre es necesario amar. ${ }^{37}$

One central feature of love poetry, and of amatory literature more generally, is that of its use as a "religious metaphor", 38 as for example in the construing of a carnal relationship as a spiritual union with the divine. The religious and secular spheres are not seen as two separate worlds, but as sharing the same symbolic world, with common referents used in both. ${ }^{39}$ The sublimation of the poet's love for his lady is the epitome of a superior and unique love, that is to say, divine love.

This phenomenon has been identified in all the peninsular literary traditions, from Arabic to Provençal. In the love poetry of Bonafed, we also find numerous religious metaphors, many of them already employed in Andalusi poetry, but charged with a new meaning in contemporary Romance literature. This may be the case in Bonafed's use of sacrificial metaphors or imitations of liturgical poems in amatory and playful contexts. Romance poetry of the period included so-called "misa de amores", "love masses" ${ }^{40}$ love poems composed to resemble the words of a mass in which the god of love is adored, with numerous quotations in Latin to round off the various stanzas of the poem. In Bonafed's moaxaja entitled Šemeš zarehah, fol. 103v-104r we find a composition with an identical function, using the model of a liturgical poem, the mustagab, with a clearly amatory content. Each stanza ends with a Biblical verse containing the name of the beloved in Hebrew: "Šemeš", i.e. "Sol". This moaxaja, as Gutwirth has pointed out, imitates the form of a mustagab, a type of selihah or penitential song which belongs to the sphere of the liturgical and not to purely playful courtly poetry, the environment within which the composition seems at first to fit. ${ }^{41}$

In the Castilian cancionero poetry ${ }^{42}$ there are various examples of love poems which take their structure from liturgical compositions, such as the miserere of

\footnotetext{
${ }^{35}$ See in M. Cátedra Tratados de amor en el entorno de Celestina.

36 ibid. 22.

37 ibid. 53 and ff.

${ }^{38}$ For the "religious metaphor" in fifteenth-century Castilian poetry, see Lida de Malkiel, "La hipérbole sagrada en la poesía Castellana." The same article, with a few additions was also published in Malkiel (ed.), Estudios sobre la Literatura Española del Siglo XV.
}

39 This same idea is suggested by Michael Camille with reference to the world of art in Camille, The Medieval Art of Love, 22.

${ }^{40}$ See for example: Juan de Dueñas, "Misa de amores" in Juan de Dueñas "La Nao de Amores. Misa de Amores" or the love mass composed by Suero de Ribera (c. 1410) in Poesía de Cancionero, edited by Alonso, 191-195.

${ }^{41}$ See Gutwirth, "A muwaššạ by Solomon Bonafed."

42 About the cancionero poetry and its importance in the fifteenth century, see the introduction to the anthology: Dutton; Roncero López, La poesía Cancioneril, 5-49. 
Francisco de Villalpando ${ }^{43}$ or the various "love masses". There are numerous examples of the use of Biblical verses inserted at the end of love poems, as in the poem "Pues mi triste corazón" ${ }^{44}$ by Pedro de Santa $\mathrm{Fe},{ }^{45}$ which uses a verse in Latin taken from Matthew 26:37-38 as the last verse of each stanza: "tristis est anima mea". Another example of the same phenomenon in the cancionero poetry is the "dezir de Maçias" ${ }^{46}$ with two stanzas which use a verse from Matthew 27:46 in Latin and Aramaic: "Deus meus, Elly, Ely e lama zabatany".

Just as these texts make playful use of the Bible and Christian liturgy, so the moaxaja of Bonafed devoted to Sol carries out the same game, although in this case basing itself on Jewish liturgy and the Hebrew Bible.

Another frequent motif in the love poetry of the period, and one which is also linked to this interaction between the religious and the amatory, is that of the sublimation of the lady and her transformation into a quasi-divine being. The concept profusely used in Provençal literature of the beloved as a unique and unequalled beauty who exceeds all other women eased the process of ascribing these virtues to the Virgin Mary, thereby sacralising love poetry.

In Hebrew literature, this association of the poet's beloved with the Virgin Mary does not occur, for obvious reasons, but we do find characterisations of the beloved as a unique being superior to all other women and to whom all must show their respect and recognition as the greatest and most beautiful (and sometimes the most wise) woman.

These idealizations respond to a scholastic conception in which beauty helps men to desire perfection and, by means of this search, come to God. The beloved and her perfect beauty thus become a reflection of divine perfection. However, as we have seen in the dialogue of Alonso Fernández de Madrigal, El Tostado, and in Bonafed's reply to Yahseel, the danger lay in carnal love and in the unbridling of the passions. If this love of pure beauty turns into sexual desire, it is transformed into a kind of madness, known as "derangement", in which passion overthrows reason.

There are many examples of descriptions of the beloved as unique and superior. ${ }^{47}$ Thus, in Juan de Mena: ${ }^{48}$

\footnotetext{
${ }^{43}$ Cancionero de Palacio, edited by Ana $\mathrm{M}^{\mathrm{a}}$ Álvarez Pellitero, poema XCIV, 78.

${ }^{44}$ Cancionero de Palacio, edited by Ana $\mathrm{M}^{\mathrm{a}}$ Álvarez Pellitero, 94-95, Poema C.

${ }^{45}$ For this poet see Vendrell de Millás, "La corte literaria de Alfonso V de Aragón y tres poetas de la misma."

${ }^{46}$ Cancionero de Palacio, edited by Ana Ma Álvarez Pellitero, 232-33, poema CCL. The attribution of the poem to Macías is uncertain.

${ }^{47}$ For the motif of the beloved as one of God's masterpieces see Lida de Malkiel, "La dama como obra maestra de Dios," 179-290.

48 Juan de Mena (1411-1456), a well-known poet from Córdoba, author of Laberinto de Fortuna, and one of the most important Castilian poets of this period.
} 
The ladies beholding you // all make petitions to God // for they ask and wish to see themselves made as you are. // But I doubt that the Lord is able to /reproduce with his hand your image in this world even though he is almighty. ${ }^{49}$

\section{In La Celestina, in the 6th act, Calisto describes Melibea's beauty as follows:}

For all those [women] who are alive today and hear of her, do curse themselves and complain to God, because he did not remember them when he made my lady. ${ }^{50}$

In one of the most paradigmatic works of chivalry, "Percival or the tale of the Grail", the lady is written of in the following terms:

"In truth, for the theft of people's hearts God made in her a prodigy, since after her he did not create another like her, nor had he created another before." 51

This is also a recurring motif in the poems of Bonafed, as can be seen from the two following examples:

"Do not reprove ${ }^{52}$ me for the love that I feel! Compared to her // the rest of women are only imitations. ${ }^{53}$ // She is the mother of all that is precious, the one whose beauty is inscrutable, // when she was created the model for all ladies was completed. ${ }^{54} / /$ The sun is ashamed of being compared with her because if her face // spat in the face of the sun, would it not bear its shame $?^{55,56}$

"There is no defect in the glorious presentation of your splendour // but the dust from which the Rock created you. // That is why I believe that the right hand of God modelled you // from the distant beginnings of your universe. // What did you leave for the rest of women if you have put // upon your shoulders, oh dove, all beauty and all greatness? // For the other girls there is only a percentage ${ }^{57}$ extracted from the harvest ${ }^{58}$ of your beauty, ${ }^{59} / /$ they collect the remains ${ }^{60}$ from your vineyard. $" 61$

\footnotetext{
49 Juan de Mena, taken from: Van Beysterveldt, La poesía amatoria del S. XV,.165:

"Las damas que vos otean //reclaman todas de Dios, // porque piden y dessean, a ssi mismas que se vean // fechas tales como vos: //mas dibdo si el Soberano // se pusiesse con su mano // con cuanto poder alcança, // en este siglo mundano // facer vuestra semejança"

${ }^{50}$ Fernando de Rojas, La Celestina, 190:

"Pues quantas hoy son nascidas que della tengan noticia, se maldizen, querellan a Dios porque no se acordó dellas quando a esta mi señora hizo."

${ }^{51}$ Chrétien de Troyes, Perceval o el cuento del Grial, 66.

${ }^{52}$ Addressed to the audience/reader.

${ }^{53}$ Literally: the image of a statue.

${ }^{54}$ Her beauty is the canon for feminine beauty. "Her beauty" is the subject of the verb "complete".

${ }^{55}$ Passage taken from $\mathrm{Nu}$ 12:14. In this passage Miriam is punished with scales and Moses prays to God to heal her. God replies: "If her father spat in her face, would she not bear her shame for seven days? Let her be shut out of the camp for seven days, and then let her be readmitted." This probably alludes to a custom in which the father spits in the face of a woman upon accusing her of something and she is banished or shut out of the community for a short period of time. In this case the lady is so beautiful that she is superior to the sun (which is even paler than her) and she is the one who can make it feel shame.

${ }^{56}$ bi me'anah 'ofrah fol. $16 \mathrm{v}-17 \mathrm{r}$. verses 6-8:

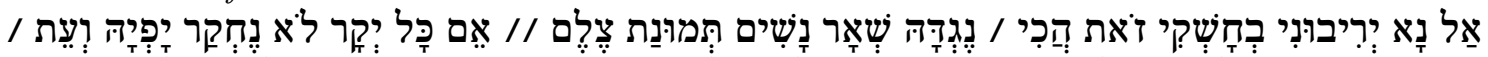

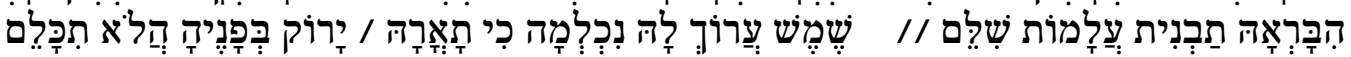

57 A donation for the priest. A portion of the harvest that is set aside to be paid as a tax to the Temple. See $\mathrm{Nu}$ 18:12.

${ }^{58}$ Literally: fields.

${ }^{59}$ The only beauty that other girls have is a portion of the whole of the beauty that belongs to the beloved.

${ }^{60}$ The grapes that are left after harvesting a vineyard, given as remains to the poor.
} 
We also find in Bonafed the need for others to recognise the incomparable beauty of his beloved and to bow down in recognition of this truth. This also occurs in novels of chivalry, highly popular in the fifteenth century, such as the story of Percival, mentioned above, where the defeated knights must recognise the superiority of the conquering knight's beloved or pledge obedience to her. ${ }^{62}$ In a similar vein, Bonafed invites his rival to recognise the insuperable beauty of his beloved:

"Go, my friend, prepare the chariot of friendship, // let us go after her and bow down to her. // Come with me, look upon her beauty and offer // to her creator exclamations for her immense beauty." ${ }^{63}$

This need for others to recognise the superiority of the beloved over all other women is carried over into the concept of the suffering of love, another widely used concept in the literature of the Cancioneros and one which also appears in the love poetry of Bonafed. The lover has to be recognised as the one who suffers most as a result of his love, as expressed by Ausias March $^{64}$ when he wrote: "I am that very extreme lover". ${ }^{65}$

Bonafed also speaks of his incomparable suffering and boasts of being the epitome of the lovesick:

"I love but I suffer, and I have become the father / of all the victims of love sickness, there is no other like me" 66

or in another poem, where Bonafed compares himself with different paradigmatic lovers:

"Alas! For none of them suffered a pain comparable to mine, / in the same way that there is no lady comparable to her in beauty.",67

The suffering caused by love is understood as a torture or penitence which becomes bearable and even desirable if one thinks of a final union with one's lady or if she one day deigns to remember her beloved, thereby freeing him from his agony. This

${ }^{61}$ Be-miṣhi ḥuqqequ, fol 15v-16v. verses 15-18:

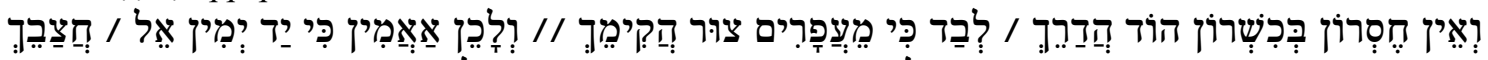

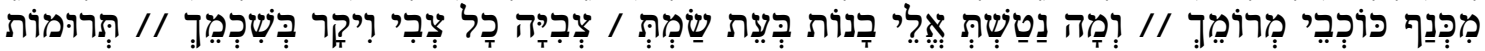

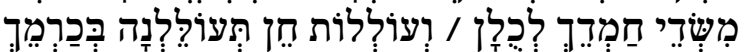

${ }^{62}$ For instance, the episode of Anguingueron defeat by Perceval in Chrétien de Troyes, Perceval o el cuento del Grial, 75.

63 te 'alah 'aletah fol. 39v-40v. verse 29 and 30.

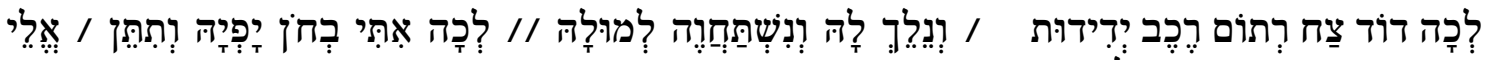

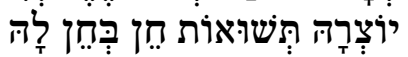

64 Ausiàs March (1400-1459): Celebrated Valencian poet who wrote in the vernacular tongue. He is considered to be the first such poet to have detached himself from the Provençal lyrical tradition.

${ }^{65}$ Ausiàs March, Páginas del Cancionero, 187, verse 41:

"Yo sòn aquell pus estrem amador"

${ }^{66}$ Šemeš be-lehyah fol 17r. verse 4:

${ }^{67}$ te 'alah 'aletah fol. $39 \mathrm{v}-40 \mathrm{v}$. verse 27 :

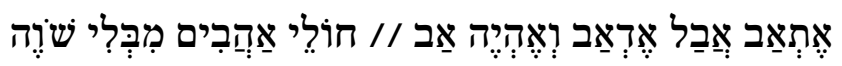

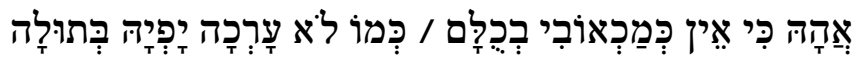


conception of suffering as something desirable because it leads to love or because it is preferable to a life without love, can be found in numerous poets of the Cancioneros, as well as in Bonafed's poetry. For example, in the poem to Simha, Bonafed explains to his beloved why he punishes himself with the passion he feels for her:

"Since your wish is to make me suffer / I will enjoy my suffering and I will not blame you. // For me it is easy to suffer a thousand years of pain / in exchange for spending one day of happiness enjoying your taste. ${ }^{\prime 68}$

In another poem, written to Malkha, Bonafed says:

"I would prefer the worst plague ${ }^{69}$ or the fetid tomb ${ }^{70} /$ to being without her love." 71

This presentation of the suffering of love as something to be desired in the hope of eventual acceptance can be seen in many poets of the Cancioneros, as for example in Sánchez de Badajoz's poem:

"Even if your cruelty lasted a thousand years //and then you forgot me, //I would have rest in Hell, //my lady, if only you would choose //a fortunate day to remember me.,"72

Physical descriptions of the beloved place great emphasis on her face and on her lover's sense of sight. Sense of sight acquires a capital importance and the face of the beloved is an image which is indelibly engraved on lovers' retinas by their gaze. Thus in the poem of Jordi de Sant Jordi ${ }^{73}$ the poet declares that the image of his beloved is engraved on his forehead (or his eyes), ${ }^{74}$ and that it cannot be erased even by death:

On my forehead I carry your beautiful likeness, for which reason I rejoice day and night, for contemplation of the very beautiful figure has left [engraved] the imprint of your face in such a way that even if I die the form will not wither, what will happen rather is that when I am completely out of this world, those who carry my body to the sepulchre will see your sign on my face. ${ }^{75}$

${ }^{68}$ be-mișhi ḩuqqequ fol. 15v-16v. verse 35-36:

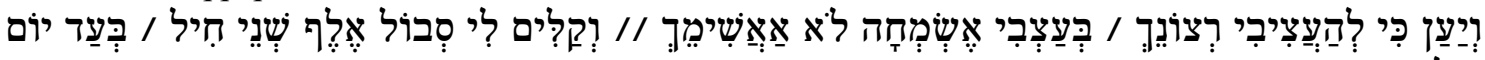

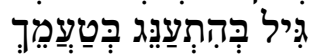

${ }^{69}$ Is 1:5. Literally: "Head of sickness" or "sick head" in the Biblical context of the quotation.

${ }^{70}$ Is 38: 17. Literally: "A tomb with no good" but in $\mathrm{RaDaK}$ it is said: "....and this is the tomb in which the corpse decomposes."

${ }^{71}$ Šemeš be-lehyah fol $17 \mathrm{r}$. verse 5:

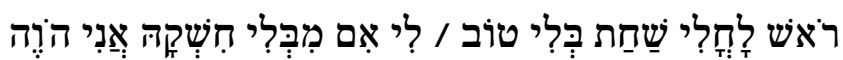

${ }^{72}$ Taken from Van Beysterveldt, La poesía amatoria del S. XV, 168, (Poema 1.045 de Sánchez de Badajoz.):

“...Y aunque mil años durasses / en tu saña y me oluidasses, / allí ternia reposo, / señora, si señalases / vn tiempo tan venturoso / en que de mi te acordasses."

${ }^{73}$ Jordi de Sant Jordi (Valencia ?-1425): Catalonian poet of the court of Alfonso V the Magnanimous.

${ }^{74}$ De Riquer, the poem's editor, explains that the meaning of the word "lo front", usually translated as "forehead" or "front part" should be understood in this poem to mean "eyes", since the poet looks upon his beloved with such adoration that her image is engraved on his eyes, which are in his "forehead". I have taken Riquer's interpretation into account in my translation of Bonafed's verse.

${ }^{75}$ De Riquer, Jordi de Sant Jordi, 147:

"Jus lo front port vostra bella semblança // de que mon cors nit e jorn fa gran festa, // que remiran la molt bella figura / de vostra faç m'es romassa l'empremta / que ja per mort no se'n partra la forma, / ans quant seray del tot fores d'est segle, // çels qui lo cors portaran al sepulcre // sobre ma faç veuran vostre signe." 
Bonafed uses this motif of the image of the beloved engraved upon his forehead/eyes, but in his work it serves to certify that the beloved cannot attempt to injure him by throwing stones at him, for this would mean throwing stones at her own image, placed as it is on the poet's forehead/eyes:

"Your face and figure are inscribed on my forehead, ${ }^{76} / /$ Oh gracious doe!, Would you kill yourself // shooting against my face the stones of your diamonds // with the mighty right hand of your love?",77

This idea of the importance of the gaze and the image of the beloved is deeply rooted in the troubador love tradition and in that of so-called courtly love. In the world of art and artistic objects the importance of this gaze and the image perceived by the lover becomes patent. ${ }^{78}$ The woman is usually the emitter of the light which is captured by the man's gaze. One interesting example of a graphic representation of the "look of love" is found in an early fifteenth-century Italian tray painted in oils which is conserved in the Louvre Museum. ${ }^{79}$ In this painting, a group of paradigmatic lovers including Tristan, Lancelot or Samson kneel in a circle and look upon a female figure identified with Venus - rays are directed from their eyes to the woman's sexual organs.

The vision of the face or figure of the beloved is not only physical. It is also present in the imaginary world of the poet, in dreams or mere thoughts. One of the bestknown figures of courtly love is that of the contemplation of the beloved through the eyes of the mind. Thus, in the work which might be considered the compendium of courtly love par excellence, the treatise by Andreas Capellanus entitled De Amore, ${ }^{80}$ we see how the physical presence of the beloved is not necessary to a vision of her, for her image is always in the lover's thoughts:

The man says: Although I rarely find myself in your presence physically, in my heart and soul I never leave you; for since you are my constant thought I do not cease to be in your presence, and this makes me see always with the eyes of my heart the treasure to which I aspire and this brings me as much turmoil as joy. ${ }^{81}$

In Bonafed's poem be-miṣhi huqqequ, addressed to the young Simḥa, there is a section in which the young woman's beauty is described, but through a dream-vision of

\footnotetext{
${ }^{76}$ Probably "my eyes", as in the poem of Jordi de Sant Jordi: Jus lo front port vostra bella semblança. (De Riquer, Jordi de Sant Jordi, 37). The first verse is identical.

${ }^{77}$ be-mishi huqqequ, fol. 15v-16v. verses 1-2:

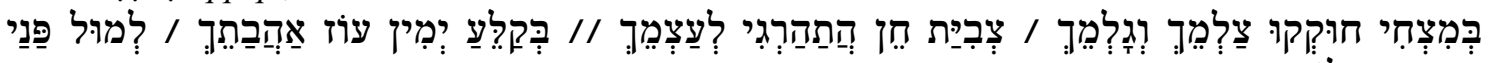

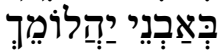

${ }^{78}$ For the look of love, see the chapter on the subject in Camille, The Medieval Art of Love, 27-49.

${ }^{79}$ Venus Venerated by Six Legendary Lovers. Birth tray made in Florence, c. 1400. Musée du Louvre. Picture and extensive commentary in Camille, The Medieval Art of Love, 19.

${ }^{80}$ Andreas Capellanus, De Amore.

${ }^{81}$ Andreas Capellanus, De Amore, 132:

"Homo ait: Licet me raro corporaliter vestro repraesentem aspectui, corde tamen et animo a vestra nunquam abscedo praesentia; assidua namque de vobis habita cogitatio saepe saepius me vobis praesentem constituit et illum thesaurum, circa quem mea versatur intentio, cordis me facit oculis semper aspicere poenasque mihi affert et solatia multa."
} 
the poet. Bonafed declares that he alone sees her image and that he remembers her face in his mind:

"While I am dwelling in the place where the hardness of separation hides, ${ }^{82}$ // I calm [my] thoughts with the vision of her power. ${ }^{83} / / \mathrm{I}$ spend pleasant moments gazing at the glory of your face and body with the eyes of my heart." ${ }^{\circ 4}$

In the troubador tradition and the literary tradition of so-called "courtly love" 85 there exists a terminological and conceptual repertoire with which Bonafed's poetry seems to share common values. Several concepts appear frequently in troubador poetry and have been widely discussed by scholars, obtaining varying results which depend on the application given by each poet to this terminology or to the diachronic development of the concepts. ${ }^{86}$ This terminology refers to different features of courtly love, to the virtues and moods of lovers or to the social universe in which these poets write. This terminological repertoire varies over time and often changes its referents, but I will now mention some of the different concepts used by Bonafed in his poems.

The first of these concepts is that of the "art of love". This notion was not original to the Provençal tradition and had appeared in classic treatises such as Ovid's "ars amatori". ${ }^{87}$ Ovid's work was widely known and profusely copied during the early fifteenth century. The term implies the conception of love as something that is constructed by following certain rules and it is found with this same meaning in a poem by Bonafed which reads as follows:

"I will look forward to the day in which our work ${ }^{88}$ of love will // be completed and I will sit you in the lap of my love." ${ }^{\prime 9}$

The Hebrew term used here is "mal'ekhet 'ahavenu", "our art/craft of love" which parallels the concept as used in the amatory tradition of Romance and Provençal literature.

\footnotetext{
${ }^{82}$ Also: "a place where the dove's power hides".

${ }^{83}$ This could also be read as "I flatten [my] thoughts with the vision of her power" or "I compare the thinking to the vision of her power", or "calm my thoughts with the vision of her power".

${ }^{84}$ be-mișhi huqqequ fol. $15 \mathrm{v}-16 \mathrm{v}$. verses 19 and 20:

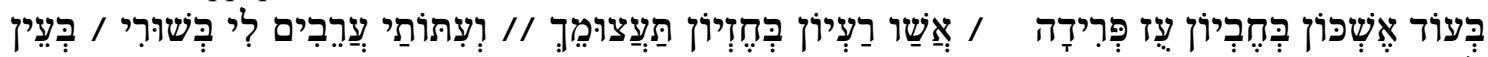

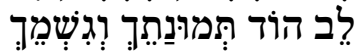

${ }^{85}$ This is not the place to discuss the controversial concept of "courtly love" and its implications for the history of Romance literature. For a summary see, for example: Topsfield, Troubadours and love; C. Moore, "Courtly Love"; M. Ferrante, "Cortes' Amor in Medieval Texts."

${ }^{86}$ For a more detailed description see the introduction to De Riquer, Los Trovadores. Historia literaria y textos.

${ }^{87}$ Publio Ovidio Nasón, Obra Amatoria.

${ }^{88}$ Ars = מלאכת אהבינו, the same expression as Ovid's title of his treatise on love, Ars amatoria. It may have something to do with the "works of love" that also appear in Text 6, verse 27.

${ }^{89}$ be-mișhi huqqequ, fol. $15 \mathrm{v}-16 \mathrm{v}$. verse 38 :
} 
Another of the concepts which appears in the love poetry of Bonafed and which he seems to share with the other Romance traditions of his time is that of the "labours of love", a concept with a long and varied life and one which is also found in the repertoire of Provençal courtly love, where the "labours" are understood as the deeds a knight must perform or the adventures he must undertake in order to win his lady's favour or the final prize of union with her. In a poem written by Bonafed to his friend Yosef (Vidal/ Gonzalo de la Caballería), we find this same concept expressed by a Hebrew term which is a calque of the Romance term "labour": "avodah":

"Give strength, lovers ${ }^{90}$ ! Give strength to the wine ${ }^{91} /$ which will suddenly enrich the heart of poor and insignificant men. // Be strong in your love, and suffer your labours." 92

Perhaps one of the most frequently recurring concepts in Bonafed's amatory poetry is that of the "law of love", widely used in fifteenth-century cancionero poetry, both Castilan and Catalan, and also in the troubador tradition. This concept is central in Provençal amatory literature and even provides the title of the treatise on Provençal poetics composed by Guilhem Molinier de Tolosa which had been commissioned by the Consistori de la Gaya Sciencia: Leys d'amor. ${ }^{93}$

This concept is also found in the Roman de la rose, ${ }^{94}$ the emblematic allegorical tale of courtly love, which was also widely known in fifteenth-century Aragon. This work contains a section in which the character embodying Love explains his "commandments" or "laws", which must be respected by lovers. Love becomes a legal code of conduct which must be respected by lovers if they wish to succeed. These commandments instruct lovers in "good love", and are compulsory for any good knight.

In the wedding poem that Bonafed composed for Yosef, the bridegroom at the wedding of Agramonte, ${ }^{95}$ Bonafed describes a scene in which the bride, beneath the nuptial canopy, holds in her hands some "tables of the law", like those held by Moses at the revelation of Sinai. The tables described by Bonafed carry engraved scenes of Biblical lovers in idyllic gardens surrounded by rivers and glades. The tables contain the "laws of love" and the scenes serve to instruct the lovers with visual examples ${ }^{96}$. The

\footnotetext{
90 "Deeds of desire or love", "the ones who belong to love".

91 verbatim: daughter of the vine.

92 'aloz lev 'asir tiqva, in Schirmann, Ha-sira, Vol 2, 625, verses 14-15:

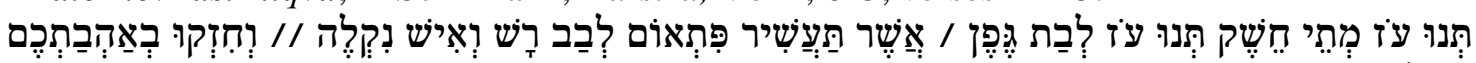

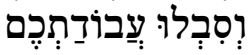

93 Joseph Anglade, Las Leys d'amors.

${ }^{94}$ Guillaume de Lorris, Le roman de la rose, 19.

${ }^{95}$ For this event see Vardi, "A wedding in Agramunt."

${ }^{96}$ It is unavoidable to mention here the profusion of ivory relifs for casquets and mirrors from the fourteenth century in the French area in which sceens of love are engraved. An enormous collection of such sceens can be seen in the permanent exposition at the Musée du Louvre. As an example see: Camille, The Medieval Art of Love, 54.
} 
bride becomes the "sage" who transmits the laws of love. Bonafed describes the image as follows:

"I see the doe and she holds in her hands something resembling the tables of the law, / it is the Law of Love with which she instructs those who love. // There are engraved the lovers ${ }^{97}$ in relief ${ }^{98}$ and there / are the effigies of the damsels forged ${ }^{99}$ by love." 100

On some occasions, Bonafed's verses can only be understood by reference to the kind of topoi and concepts found in Romance amatory literary traditions, and especially in those of the troubadors. Without such references, the interpretation of certain verses would be impossible, as occurs in the poem in which Bonafed rebukes his beloved in the following terms:

"Is it fair, turtle dove, that you wrong your friend / with gentle responses"101 and that the orphan suffers ${ }^{102}$ ?"103

The key to understanding this particular verse lies in the concept of "gentle responses". The beloved confuses her lover with "gentle responses", but she does not allow herself to be conquered and neither does she accept his love. This is a well-known theme in courtly love poetry. At the beginning of the Roman de la Rose, the main character falls in love with a lady who "spoke to him and treated him with good manners". ${ }^{104}$ The beloved receives the lover with "good manners", regaling him with a "good reception" but she soon rejects him and refuses to love him. The figure of "good manners" becomes an allegory in the Roman de la Rose, and is characterised as a handsome young man who is the son of courtesy and is presented in verse 2789 as "Bel Acueil" 105 or "Good welcome".

In this verse Bonafed seems to refer to the Provençal concept of the beloved's "welcome" with her "gentle responses", and he appears to follow the Romance amatory

\footnotetext{
97 "Those who desire/suffer the pangs of love".

${ }^{98} \mathrm{Ez} 23,14$. Some commentators refer to the colour "carmine" or "red". Others interpret this as referring to a form of engraving in relief, or a drawing. The second meaning seems most suited to the context.

${ }^{99}$ In the sense of casting i.e. melting the metal in a die to make a statue. Love has been the creator of these images engraved in stone and cast in metal. The word "image" also means "mould" or "die". The same verb can also be used to mean "join" (see Vardi, "A wedding in Agramunt", 93). If this were the case, it would be love that "joined" the pairs of lovers alluded to by the poet in the verses that follow.

100 yonah be-tokh sipporim, fol. 56r-57r, the poem was published in: Vardi, "A wedding in Agramunt", 169-196, verses 13-14:
}

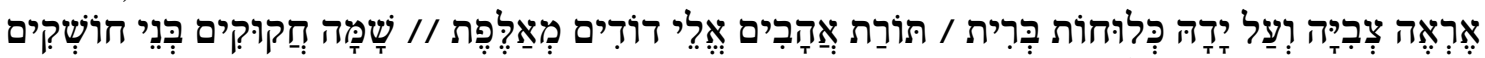

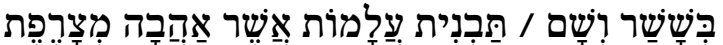

101 This plays with the reference to the proverb in Pro 15:1 "A gentle response allays wrath, a harsh word provokes anger". In this case "a gentle response" causes more pain to the lover, because it is gentle but not positive.

${ }^{102} \mathrm{He}$ is playing with God's order in Je 22:3 "do not wrong the stranger, the fatherless, and the widow". Bonafed is accusing the beloved of not fulfilling God's law. She is "doing wrong to the fatherless".

${ }^{103}$ be-miṣhi huqqequ, fol. $15 \mathrm{v}-16 \mathrm{v}$. verse 22 :

${ }^{104}$ See Guillaume de Lorris, Le roman de la rose, 19

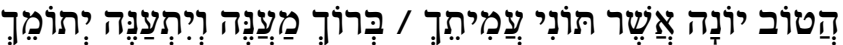

${ }^{105}$ Guillaume de Lorris, Le roman de la rose, 190. 
courtly tradition of his time. The same motif appears in the work of several troubadors, such as Rigaut de Berbezilh:

[If your hard heart were the equal of the courtesy which makes your conversation so pleasant, it would be easy for you to think of me that I would rather kill myself than beg you.... ${ }^{106}$

or in another poem by Berenguer de Palou:

[She does not promise, nor concede, nor remove, nor lack nor lie, but she knows how to say no so gently that at the time you believe that she has acceded to all of your supplications.] ${ }^{107}$

In this article, then, I have sought to illustrate the relationship that exists between Bonafed's poetry and Romance literature. While the connection between the motifs of fifteenth-century Hebrew literature and their Andalusi Hebrew counterparts is clear, this connection derives from the fact that there will always be formal literary parallels between the "classical literature" adopted by a later society as a "cultural banner" and the real literary production of that society. However, there is a difference between what fifteenth-century poets said about "their literature" and what they actually wrote.

These poets claim to consider themselves the heirs of a tradition which went back to the Biblical prophets and took in a number of Andalusi poets, mainly Yehuda Halevi, the ibn Ezras (this probably refers to Abraham and Moshe) and Shelomo ibn Gabirol, to end in Shelomo de Piera and Bonafed himself. However, the literature of Bonafed and Shelomo de Piera is not a straightforward attempt to recreate the literature of another time and another culture, even though it is written in the same Hebrew language. It is, rather, a "new literature" created for a different society which shares a common cultural framework with the other Romance literatures of its period. I hope this article will help to contextualize the literature written by Bonafed within his time and its cultural complexity.

\footnotetext{
106 De Riquer, Los Trovadores. Historia literaria y textos, vol. 1, 294: "Si.l vostre durs cors fos taus // com la cortesia // que.us fai d'avinen parlar, // leu pogratz de mi pensar // qu'anz m'auseria // que.us preges..."

107 De Riquer, Los Trovadores. Historia literaria y textos, vol. 1, 304: "Ilh no promet ni autreya // ni estría ni falh ni men, // mas de no sap dir tan gen // qu'ades cuydaretz que deya // totz postres precx obecir;"
} 


\section{BIBLIOGRAPHY}

Alonso, Álvaro. Poesía de Cancionero. 1st ed. 1986.

Alvar, Carlos and Lucía Megías, José Manuel. Repertorio de traductores del siglo XV. Madrid: Ollero y Ramos, 2009.

Anglade, Joseph. Las Leys d'amors. Manuscrit de l'académie des jeux floraux Toulouse: Privat, 1919.

Ausiàs March, Páginas del Cancionero, introduction, edition and notes by Costanzo di Girolamo; translation by José María Micó. Madrid: Editorial pre-textos, 2004.

Bolduc, Michelle. "The Breviari d'Amor: Rethoric and Preaching in Thirteenth-Century Languedoc.” Rhetorica 14: 4 (2006): 403-426.

Camille, Michael. The Medieval Art of Love, New York: Harry N. Abrams, 1998.

Cancionero de Palacio, edited by Álvarez Pellitero, Ana M ${ }^{\mathrm{a}}$. Salamanca: Junta de Castilla y León / Consejería de Cultura y turismo, 1993.

Capellanus, Andreas. De Amore, edited and translated by Creixell Vidal-Quadras, Inés. Barcelona: El Festín de Esopo, 1985.

Chrétien de Troyes. Perceval o el cuento del Grial, edited and translated by Martín de Riquer. 5th ed. Madrid: Espasa Calpe. 1961.

De Riquer, Martín. Los Trovadores. Historia literaria y textos. 3 vols. 1st ed. 1975. Ariel: Barcelona 1989.

Dutton, Brian. and Roncero López, Victoriano. La poesía cancioneril del siglo XV: Antología y estudio. Madrid; Frankfurt: Iberoamericana; Vervuert. 2004

Fernando de Rojas, La Celestina, 1st ed. 1987. Edited by Dorothy S. Severin. Madrid: Catedra, 2007.

Gómez Moreno, Ángel. España y la Italia de los humanistas: Primeros Ecos. Madrid: Gredos, 1994.

Guillaume de Lorris, Le roman de la rose. El libro de la rosa. Edited by Alvar, Carlos. Barcelona: El festin de Esopo, 1985.

Gutwirth, Eleazar. "Social Criticism in Bonafed's Invective and its Historical Background." Sefarad 45 (1985): 23-53.

_“The World Upside Down in Hebrew.” Orientalia Suecana 30 (1981):141-47.

-"Leer a Bonafed en su entorno." In La Sociedad Medieval a través de la Literatura Hispano-judía, edited by Ricardo Izquierdo Benito and Ángel Sáenz-Badillos, 341-357. Cuenca: Ediciones de la Universidad de Castilla-La Mancha, 1998.

-“A muwaššah by Solomon Bonafed.” In Poesía Estrófica: Actas del Primer Congreso Internacional sobre Poesía Estrófica Árabe y Hebrea y sus Paralelos Romances (Madrid, 
diciembre de 1989), edited by Federico Corriente and Ángel Sáenz-Badillos, 137-144. Madrid: Universidad Complutense, 1991.

Japhet, Sara. "The Lovers'Way": Cultural Symbiosis in a Medieval Commentary on the Song of Songs." In Birkat Shalom. Studies in the Bible, Ancient Near Eastern Literature, and Postbiblical Judaism. Presented to Shalom M. Paul on the Ocassion of His Seventieth Birthday, edited by Chaim Cohen et alii. Vol. 2. 863-880. Indiana: Eisenbrauns, 2008.

Jordi de Sant Jordi, Jordi de Sant Jordi, edited and translated by De Riquer, Martín. Granada: Universidad de Granada, 1955.

Juna de Dueñas. Juan de Dueñas "La Nao de Amores. Misa de Amores.” Edited by Presotto, Marco. Viareggio; Lucca: Mauro Baroni, 1997.

Lida de Malkiel, María Rosa. "La hipérbole sagrada en la poesía Castellana del s. XV." Revista de Filología Hispánica 8 (1946): 121-130.

-"La dama como obra maestra de Dios." in Estudios sobre la Literatura Española del Siglo XV, edited by Yakov Malkiel. 179-290.Madrid: Turanzas, 1977.

M. Cátedra, Pedro. Tratados de amor en el entorno de Celestina (Siglos XV- XVI), Madrid: Sociedad Estatal España Nuevo Milenio, 2001.

M. Ferrante, Joan. “Cortes' Amor in Medieval Texts.” Speculum 55:4 (1980): 686-695.

Moore C., John. "Courtly Love": A problem of Terminology." Journal of the history of ideas, 40:4 (1979): 621-632.

Morgan, Gerald. "Natural and Rational Love in Medieval Literature." The Year Book of English Studies, 7 (1977): 43-52.

Publio Ovidio Nasón, Obra Amatoria I: Amores. Edited by Ramírez de Verger, Antonio. Translated by Socas, Francisco. Madrid: CSIC, 1991.

Sáenz-Badillos, Ángel. "Relaciones entre la poesía hebrea y las literaturas romances. Estado actual del problema." In Estudios románicos dedicados al Profesor Andrés Soria Ortega, edited by Jesus Montoya Martínez and Juan Paredes Nuñez. Vol. 1. 515-530. Granada: Universidad de Granada, 1985.

-"Selomoh Bonafed at the crossroad of Hebrew and romance cultures." in Encuentros y desencuentros, Spanish Jewish Cultural Interaction throughout history, edited by Carlos Carrete Parrondo, Ángel Sáenz-Badillos and Francisco Villanueva. 343-80. Tel-Aviv: University Publishing Projects, 2000.

-“Šelomoh Bonafed, último gran poeta de Sefarad, y la poesía hebrea.” eHumanista 2 (2002): 1-22.

Scheindlin, Raymond P. "Secular Hebrew Poetry in fifteenth-century Spain.” In Crisis and Creativity in the Sephardic World 1391-1648, edited by Benjamin R. Gampel. 25-37. New York: Columbia University Press, 1997. 
-"The Hebrew Qasida in Spain." In Qasida Poetry in Islamic Asia and Africa, edited by Stefan Sperl and Christopher Shackle. Vol. 1. 128-135. Leiden; New York: E.J. Brill, 1996.

Schirmann, Jefim, Ha-širah ha-'ivrit bi-Sefarad u-ve-Provans. Vol. 2. Jerusalem: The Bialik Institute and Devir, 1954.

Targarona Borrás, Judit. "Los últimos poetas hebreos de Sefarad: poesía hebrea en el mundo románico.” Revista de Filología Románica 19 (2002): 249-268.

Topsfield, L.T. Troubadours and love, London. NY. Melbourne: Cambridge University Press, 1975.

Vardi, Tirza. "A wedding in Agramunt: The wedding poems of Solomon Bonafed." (Heb.) Mehqare yerušalayim be-sifrut 'ivrit 14 (1993): 169-196.

Van Beysterveldt, Antony. La poesía amatoria del S. XV y el teatro profano de Juan del Encina, Madrid: Insula, 1972.

Vendrell de Millás, Francisca. "La corte literaria de Alfonso V de Aragón y tres poetas de la misma (Conclusión.)" Boletín de la Real Academia Española 19 (1932): 85-100; 468-484; 584-607; 20 (1933): 69-76. 